BMJ Open

Sport \&

Exercise

Medicine

\section{Prevalence of depression and anxiety in top-level male and female football players}

To cite: Junge $A$,

Feddermann-Demont N. Prevalence of depression and anxiety in top-level male and female football players. BMJ Open Sport Exerc Med 2016;2: 000087. doi:10.1136/bmjsem-2015000087

- Prepublication history for this paper is available online. To view these files please visit the journal online (http://dx.doi.org/10.1136/ bmjsem-2015-000087).

Received 7 November 2015 Accepted 17 November 2015

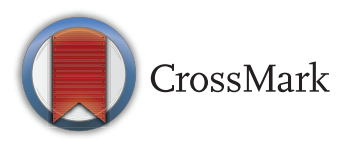

\footnotetext{
${ }^{1}$ Medical School Hamburg (MSH), Hamburg, Germany ${ }^{2}$ FIFA Medical Assessment and Research Centre (FMARC), Zürich, Switzerland ${ }^{3}$ Swiss Concussion Centre (SCC) Schulthess Klinik, Zürich, Switzerland ${ }^{4}$ Department of Neurology, Interdisciplinary Center for Vertigo and Neurological Visual Disorders, University Hospital Zürich, Zürich, Switzerland
}

Correspondence to Dr Astrid Junge; Astrid. Junge@F-MARC.com

\section{ABSTRACT}

Background: Scientific studies on the prevalence of mental health problems in elite athletes are rare, and most have had considerable methodological limitations, such as low response rate and heterogeneous samples. Aims: To evaluate the prevalence of depression and anxiety in top-level football players in comparison to the general population, and to analyse potential risk factors.

Methods: Players of all first league (FL) and of four U-21 football teams in Switzerland were asked to answer a questionnaire on player's characteristics, the Centre of Epidemiologic Studies Depression Scale (CES-D) and the Generalized Anxiety Disorder (GAD-7) scale.

Results: All 10 women's FL teams, 9 of 10 men's FL teams and 4 male $U-21$ teams ( $n=471$ football players) took part in the study. The CES-D score indicated a mild to moderate depression in $33(7.6 \%)$ players and a major depression in $13(3.0 \%)$ players. The GAD-7 score indicated an at least moderate anxiety disorder in $6(1.4 \%)$ players. Compared to the general population, the prevalence of depression was similar and the prevalence of anxiety disorders was significantly $\left(\chi^{2}=16.7 ; p<0.001\right)$ lower in football players. Significant differences were observed with regard to player characteristics, such as age, gender, player position, level of play and current injury.

Conclusions: Swiss FL football players had the same prevalence of depression as the general population, while male U-21 players had a higher prevalence of depression. It is important to raise awareness and knowledge of athletes' mental health problems in coaches and team physicians, and to provide adequate treatment to athletes.

\section{INTRODUCTION}

Despite some prominent cases (eg, Reng and Enke, ${ }^{1}$ Biermann and Schäfer, ${ }^{2}$ Rafati $\left.{ }^{3}\right)$, mental health problems are rarely reported in football and other sports. It is possible that the physical activity, ${ }^{4}$ the team support or the 'privileged' life (eg, financial security, access to various resources, admiration from the public) associated with professional football protects these players from getting

\section{What are the new findings?}

- Swiss first league (FL) football players have the same prevalence of depression as the general population, while male U-21 players have a higher prevalence of depression.

- Symptoms of a severe depression were present in on average one player of each female $\mathrm{FL}$ team and each male U-21 team, as well as in one player in two male FL teams.

- Six $(1.4 \%)$ players had an at least moderate anxiety disorder, which is a significantly lower prevalence than that seen in the general population.

- Significant differences were observed with regard to player characteristics, such as age, gender, player positions, level of play and current injury.

How might it impact on clinical practice in the near future?

- Awareness and knowledge of athletes' mental health problems need to be raised in coaches and team physicians.

- Adequate psychotherapeutic and/or pharmacological treatment should be provided to athletes in need.

mental disorders, or that people with a predisposition for mental disorders do not become high-level athletes. But it is also possible that the stigma attached to mental health issues makes it an under-investigated and under-reported area in top-level football and other elite sport. ${ }^{6-8}$

Scientific studies on the mental health of athletes are rare, ${ }^{9-11}$ and their results are inconsistent. Many studies focused on college athletes in the USA, ${ }^{12-18}$ and few investigated the top-level national athletes. ${ }^{19-21}$ Many studies included athletes from various sports without providing prevalence data for specific types of sport. $^{12}{ }^{13}{ }^{17-20} \quad 22 \mathrm{Up}$ to now, only one study reported mental health problems of active high-level male football 
players. ${ }^{23}$ A further study analysed career-time mental health problems of female elite football players (Prinz and Junge, submitted). Some studies had a low response rate $\left(\mathrm{eg}, 25.1 \%^{19} ; 29 \%^{23}\right)$, and others did not even report it. ${ }^{12} 151820{ }^{24}$ This is a serious methodological limitation, since potential selection effects might have biased the reported prevalence.

Most studies on mental health of active athletes have investigated depression, and few have looked into anxiety, eating disorders, abuse of alcohol or unspecific mental health problems such as distress and burnout. Depression was most frequently measured using the Centre of Epidemiologic Studies Depression Scale $\left(\right.$ CES-D $\left.{ }^{25}\right)$ (table 1). For other mental health problems, various measurements were used, which makes a comparison of results and, consequently, a conclusion on the prevalence, almost impossible.

The percentage of athletes classified as depressed varied from $3.6 \%{ }^{21}$ to $37 \%^{24}$; if results solely based on the CES-D were regarded, the range was still $16 \%{ }^{15}$ to $36 \% .{ }^{12}$ In most studies, a higher prevalence of depression in female rather than in male players was reported. ${ }^{12} 13{ }^{18-20}$ Nixdorf $e t a l^{20}$ found different prevalence rates of depression in professionals $(15 \%)$, and junior (20\%) and amateur athletes (29\%), however, the means of these groups were similar. Further, significantly

Table 1 Studies on depression of active athletes

\begin{tabular}{|c|c|c|c|c|}
\hline $\begin{array}{l}\text { Author, year, } \\
\text { country }\end{array}$ & $\begin{array}{l}\text { Number and characteristics } \\
\text { of athletes ( } M=\text { male; } \\
\mathrm{F}=\text { female) }\end{array}$ & $\begin{array}{l}\text { Response } \\
\text { rate }\end{array}$ & Assessment method & $\begin{array}{l}\text { Results mean (SD); \% } \\
\text { (M=male; F=female) }\end{array}$ \\
\hline $\begin{array}{l}\text { Gulliver 2014, } \\
\text { Australian }\end{array}$ & $\begin{array}{l}224 \text { elite athletes from various } \\
\text { sport } \\
\text { M: } 106 ; \mathrm{F}: 118\end{array}$ & $25.1 \%$ & CES-D cut-off 16 & $\begin{array}{l}\text { M: } 10.33 \\
F: 16.67 \\
M: 23.6 \% ; F: 30.5 \%\end{array}$ \\
\hline $\begin{array}{l}\text { Yang et al } 2014,{ }^{14} \\
\text { USA }\end{array}$ & $\begin{array}{l}330 \text { NCAA division I American } \\
\text { Football players; M: 256; F: } \\
131\end{array}$ & $\begin{array}{l}88.9 \% / \\
84.3 \%\end{array}$ & CES-D cut-off 16 & $20.0 \%$ \\
\hline $\begin{array}{l}\text { Proctor and } \\
\text { Boan-Lenzo 2010, } \\
\text { USA }\end{array}$ & $\begin{array}{l}66 \text { male division I baseball } \\
\text { players }\end{array}$ & Not reported & CES-D cut-off 16 & $\begin{array}{l}M: 8.76(S D=0.82) \\
M: 15.6 \%\end{array}$ \\
\hline $\begin{array}{l}\text { Armstrong and } \\
\text { Oomen-Early 2009, }{ }^{12} \\
\text { USA }\end{array}$ & $\begin{array}{l}104 \text { NCAA division I athletes } \\
\text { from various sport; M: } 47 ; \mathrm{F} \text { : } \\
57\end{array}$ & Not reported & CES-D cut-off 16 & $\begin{array}{l}M: 11.70(S D=6.86) \\
F: 15.49(S D=10.34) \\
33.5 \%\end{array}$ \\
\hline $\begin{array}{l}\text { Yang et al } 2007,,^{13} \\
\text { USA }\end{array}$ & $\begin{array}{l}257 \text { NCAA division I athletes } \\
\text { from various sport; M: } 167 ; \mathrm{F} \text { : } \\
90\end{array}$ & $77.3 \%$ & CES-D cut-off 16 & $\begin{array}{l}\text { M: } 19.2 \% \\
F: 25.6 \%\end{array}$ \\
\hline $\begin{array}{l}\text { Brewer and Petrie } \\
1995,{ }^{16} \text { USA (zit } \\
\text { from }^{11} \text { ) }\end{array}$ & $\begin{array}{l}916 \text { NCAA division I American } \\
\text { Football players }\end{array}$ & & CES-D cut-off 16 & $27 \%$ \\
\hline $\begin{array}{l}\text { Nixdorf et al } 2013,{ }^{20} \\
\text { Germany }\end{array}$ & $\begin{array}{l}162 \text { athletes from various type } \\
\text { and level of sport; M: 104; F: } \\
58\end{array}$ & Not reported & CES-D cut-off 23 & $\begin{array}{l}\text { M: } 12.6 \text { (SD missing) } \\
\text { F: } 13.4 \text { (SD missing) } \\
19 \%\end{array}$ \\
\hline $\begin{array}{l}\text { Weigand et al } 2013,{ }^{17} \\
\text { USA }\end{array}$ & $\begin{array}{l}163 \text { NCAA athletes from } \\
\text { various sport; gender: not } \\
\text { reported }\end{array}$ & $49.4 \%$ & $\begin{array}{l}\text { Wakefield Depression } \\
\text { Scale }>14\end{array}$ & $\begin{array}{l}8.67(\mathrm{SD}=5.75) \\
16.8 \%\end{array}$ \\
\hline $\begin{array}{l}\text { Storch et al 2005, } \\
\text { USA }\end{array}$ & $\begin{array}{l}105 \text { division I athletes from } \\
\text { various sport; } \\
\text { M: } 54 \text {; F: } 51\end{array}$ & Not reported & $\begin{array}{l}\text { Depression subscale of } \\
\text { PAI }\end{array}$ & $\begin{array}{l}\text { M: } 3.7 \% \\
F: 9.8 \%\end{array}$ \\
\hline $\begin{array}{l}\text { Spengler et al } 2013,{ }^{22} \\
\text { Germany }\end{array}$ & $\begin{array}{l}150 \text { elite and recreational } \\
\text { athletes; } \\
\text { Gender: not reported }\end{array}$ & $57.7 \%$ & WHO-5 & $\begin{array}{l}15 \% \text { recommended for } \\
\text { further evaluation for } \\
\text { depression }\end{array}$ \\
\hline $\begin{array}{l}\text { Gouttebarge et al } \\
2015,{ }^{23} 6 \text { countries }\end{array}$ & $\begin{array}{l}149 \text { male professional football } \\
\text { player }\end{array}$ & $29 \%$ & GHQ-12 & $\begin{array}{l}26 \% \text { symptoms of anxiety } \\
\text { and depression }\end{array}$ \\
\hline $\begin{array}{l}\text { Hammond et al } \\
2013,{ }^{24} \text { Canada }\end{array}$ & $\begin{array}{l}50 \text { swimmers competing at } \\
\text { national level; } \\
\text { M: } 28 ; \mathrm{F}: 22\end{array}$ & Not reported & $\begin{array}{l}\text { Semistructured } \\
\text { interview for DSM-IV, } \\
\text { BDI-2 }\end{array}$ & $\begin{array}{l}34 \% \text { based on DSM-IV } \\
\text { interview } \\
37 \% \text { mild or moderate } \\
\text { symptoms based on BDI-2 }\end{array}$ \\
\hline $\begin{array}{l}\text { Schaal et al 2011, } \\
\text { France }\end{array}$ & $\begin{array}{l}2067(17 \%) \text { athletes' } \\
\text { evaluations, representative for } \\
\text { age and gender }\end{array}$ & $\begin{array}{l}\text { Does not } \\
\text { apply }\end{array}$ & Medical reports & $\begin{array}{l}3.6 \% \text { recent or ongoing } \\
\text { depression }\end{array}$ \\
\hline
\end{tabular}


higher average depression scores were observed in individual rather than in team sport athletes. ${ }^{20}$ Thus, differences in the athletes' characteristics may have contributed to the heterogeneous results in addition to the methodological problems mentioned above.

Very little information about the prevalence of anxiety in active athletes was found in the literature. ${ }^{13} 14181921$ In studies using different self-report questionnaires, the reported prevalence of anxiety symptoms varied between $3.8 \%^{19}$ and $22.2 \%^{18}$ in male and $10.2 \%^{19}-37.3^{18}$ in female athletes. Schaal $e t a l^{21}$ found 6 -month prevalence rates for general anxiety disorders of $5.2 \%$ in male and $7.5 \%$ in female athletes, analysing their medical records.

Therefore, the aim of the present study was to evaluate the depression and anxiety, in a homogenous and representative group of top-level male and female athletes. The prevalence of depression and anxiety will be assessed in all players of all Swiss first league (FL) football teams and compared to data of the general population. In addition, effects of player characteristics on depression and anxiety will be analysed.

\section{METHODS}

The present study was conducted as part of a larger project on concussion in football (Swiss Concussion Project), and approved by ethics commission Kanton Zürich, Switzerland. All male and female football teams of the highest league in Switzerland were invited to take part in the project. The participating players provided informed consent and filled in the questionnaire analysed in the present study during the baseline examination of the Swiss Concussion Project.

The questionnaire included questions on playing position, number of matches and training sessions, number of injuries and frequency of intake of medication (for pain, sleep, relaxation, depression, anxiety and others) in the previous 12 months, current injuries (yes/no), as well as the German version of the CES-D ${ }^{25}$ and of the Generalized Anxiety Disorder (GAD- $7^{26}$ ). The validated German versions of the CES-D and GAD-7 were used. $^{27} 28$

The CES-D ${ }^{25}$ is a self-report scale designed to measure symptoms of depression experienced in the past week. Based on the answers to the 20 items on a four-point Likert scale (0-3), a depression score between 0 and 60 is calculated. Questionnaires with more than 33\% missing values were excluded from the analysis; for questionnaires with fewer missing values, these were replaced with the individual average response. The cut-off score for mild to moderate depression is 16 , and for possibility of major depression is more than $21 .^{25}$

The GAD-7 is a seven-item questionnaire on symptoms of a GAD in the last 2 weeks. A sum score is calculated by adding the answers to the seven items on a four-point Likert scale (0-3), scores range from 0 to 21. Questionnaires with more than $33 \%$ missing values were excluded from the analysis; for questionnaires with fewer missing values, these were replaced with the individual average response. The cut-off score is 10 or more for a moderate, and 15 or more for a severe anxiety disorder. $^{26} 28$

All data were processed using Excel and SPSS. Statistical methods applied were means with SD, frequencies with percentage, correlation, $\mathrm{t}$ test, analysis of variance and $\chi^{2}$ test. Significance was accepted at $\mathrm{p}<0.05$.

\section{RESULTS}

All 10 women's teams and 9 of 10 men's teams of the first football league in Switzerland, as well as 4 male U-21 teams took part in the study. The total group comprised 471 top-level football players. The mean age of the players was 22.3 years $(\mathrm{SD}=4.47)$, and differed significantly between the three subgroups $(\mathrm{F}=103.5 ; \mathrm{p}<0.001)$ (for details see table 2).

Most of the players were midfielders $(168 ; 35.7 \%)$ and defenders $(148 ; 31.4 \%)$, followed by attackers (63; $13.4 \%)$, goalkeepers $(47 ; 10.0 \%)$ and players with more than one playing position $(22 ; 4.7 \%)$. The distribution of playing positions was similar in the three subgroups. The players had played on average 36.2 matches $(\mathrm{SD}=17.3)$ in the last 12 months. On average, male FL players played more matches than female FL players $(\mathrm{t}=3.77 \mathrm{p}<0.001)$ and male $\mathrm{U}-21$ players $(\mathrm{t}=4.94$; $\mathrm{p}<0.001)$. Based on the number of international and national matches (friendly matches excluded), players were divided into three levels of play (for details see table 2). The distribution of level of play was similar for male and female FL players but different in U-21 players $\left(\chi^{2}=9.98 ; \mathrm{p}<0.01\right.$ resp. $\left.\chi^{2}=9.73 ; \mathrm{p}<0.01\right)$.

The players had incurred on average 1.39 performance-limiting injuries $(\mathrm{SD}=1.13)$ in the last 12 months. The mean number of injuries was similar in male and female FL players, and significantly higher in $\mathrm{U}-21$ players $(\mathrm{t}=2.45 ; \mathrm{p}<0.05$ resp. $\mathrm{t}=2.41 ; \mathrm{p}<0.05)$. Almost every fifth player (17.5\%) was currently injured with no significant difference between the subgroups. Three $(0.6 \%)$ players took sleeping pills daily, one $(0.2 \%)$ a sedative/tranquiliser and one $(0.2 \%)$ took antidepressants.

\section{Depression}

The CES-D was answered by $432(91.9 \%)$ players. The response rate was significantly higher in female than in male FL players $\left(\chi^{2}=15.3 ; p<0.001\right)$, the response rate of U-21 players was between the FL subgroups and not statistically different from either (for details see table 3).

The depression score of the entire group was on average $8.60(\mathrm{SD}=5.52)$, and indicated a mild to moderate depression in $33(7.6 \%)$ players and a major depression in $13(3.0 \%)$ players. On average, 1.3 player in each male FL team, 2.3 players in each female FL team and 2.8 players in the male U-21 teams had symptoms of an at least mild depression. Symptoms of a severe depression were present in about one player per two male FL 
Table 2 Characteristics of top-level Swiss football players

\begin{tabular}{|c|c|c|c|}
\hline & \multicolumn{2}{|l|}{ Male players } & \multirow{2}{*}{$\begin{array}{l}\text { Female players } \\
\text { First league } \\
n=182\end{array}$} \\
\hline & $\begin{array}{l}\text { First league } \\
n=211\end{array}$ & $\begin{array}{l}U-21 \\
n=78\end{array}$ & \\
\hline Age & $24.81(2.27)$ & $18.35(1.18)$ & $20.95(3.76)$ \\
\hline Position & $\mathrm{N}(\%)$ & $\mathrm{N}(\%)$ & $\mathrm{N}(\%)$ \\
\hline Defender & $64(30.3)$ & $20(25.6)$ & $64(35.2)$ \\
\hline Goalkeeper & $23(10.9)$ & $5(6.4)$ & $19(10.4)$ \\
\hline More than one & $9(4.3)$ & $5(6.4)$ & $8(4.4)$ \\
\hline Number of matches & Mean (SD) & Mean (SD) & Mean (SD) \\
\hline International matches & $6.71(6.71)$ & $5.05(5.18)$ & $6.11(6.81)$ \\
\hline National matches & $26.12(10.2)$ & $19.61(9.91)$ & $24.64(11.2)$ \\
\hline 10-19 national matches & $123(58.3)$ & $43(32.3)$ & $111(61.0)$ \\
\hline >20 national matches & $54(25.6)$ & $35(44.9)$ & $47(25.8)$ \\
\hline \multirow[t]{2}{*}{ Number of injuries in the last 12 months } & mean (SD) & mean (SD) & mean (SD) \\
\hline & $1.32(1.15)$ & $1.73(1.28)$ & $1.31(1.02)$ \\
\hline Currently injured & $\mathrm{N}(\%)$ & $\mathrm{N}(\%)$ & $\mathrm{N}(\%)$ \\
\hline No & $168(86.2)$ & $58(78.4)$ & $142(80.2)$ \\
\hline Yes & $27(13.8)$ & $16(21.6)$ & 35 (19.8) \\
\hline
\end{tabular}

teams, and one player per female FL and one per male U-21 team. The CES-D score correlated significantly with the age $(\mathrm{r}=-0.178 ; \mathrm{p}<0.001)$ and number of matches $(\mathrm{r}=$ $-0.240 ; \mathrm{p}<0.001)$ but not with the number of injuries in the previous 12 months.

Male FL players had significantly lower average depression scores than male $\mathrm{U}-21(\mathrm{t}=3.76 ; \mathrm{p}<0.001)$ and female FL players $(\mathrm{t}=4.26 ; \mathrm{p}<0.001)$ (for details see table 3 ). Compared to the general population of the same gender, male and female FL players had similar average depression scores, while male U-21 players had significantly $(\mathrm{t}=4.53 ; \mathrm{p}<0.001)$ higher scores. The percentages of players with CES-D scores indicating different severities of depression were similar in the three subgroups, and all subgroups were similar to the general population of the same gender (for details see table 3).

The average depression scores differed significantly between playing positions $(\mathrm{F}=3.53 ; \mathrm{p}<0.01)$ and levels of play $(\mathrm{F}=7.70 ; \mathrm{p}=0.001)$ in the entire group (for details see table 4$)$. In the subgroups, differences were only significant for playing position in male $\mathrm{FL}$ players $(\mathrm{F}=2.57$; $\mathrm{p}<0.05)$ and for levels of play in $\mathrm{U}-21$ players $(\mathrm{F}=4.56$; $\mathrm{p}<0.05)$. Injured players had higher depression scores than uninjured players in all subgroups but the results

Table 3 Depression (CES-D) and anxiety (GAD-7) score in top-level football players and in the general population

\begin{tabular}{|c|c|c|c|c|c|}
\hline & \multicolumn{3}{|l|}{ Male } & \multicolumn{2}{|l|}{ Female } \\
\hline & $\begin{array}{l}\text { First league } \\
\text { players }\end{array}$ & U-21 players & $\begin{array}{l}\text { General } \\
\text { population }\end{array}$ & $\begin{array}{l}\text { First league } \\
\text { players }\end{array}$ & $\begin{array}{l}\text { General } \\
\text { population }\end{array}$ \\
\hline $\begin{array}{l}\text { CES-D, mean } \\
\text { (SD) }\end{array}$ & $\begin{array}{l}n=182 ; \\
86.3 \% \\
7.18(4.75)\end{array}$ & $\begin{array}{l}\mathrm{n}=73 \\
93.6 \% \\
9.89(6.20)\end{array}$ & $\begin{array}{l}n=394,{ }^{29} \\
6.6(5.6)\end{array}$ & $\begin{array}{l}\mathrm{n}=177 \\
97.8 \% \\
9.53(5.67)\end{array}$ & $\begin{array}{l}n=474,{ }^{29} \\
7.8(6.8)\end{array}$ \\
\hline$<16$ & $170(93.4 \%)$ & $62(84.9 \%)$ & $363(92.2 \%)$ & $154(87.0 \%)$ & $416(87.8 \%)$ \\
\hline $16-21$ & $10(5.5 \%)$ & $8(11.0 \%)$ & $20(5.0 \%)$ & $15(8.5 \%)$ & $36(7.6 \%)$ \\
\hline$>21$ & $2(1.1 \%)$ & $3(4.1 \%)$ & $11(2.8 \%)$ & $8(4.5 \%)$ & $22(4.6 \%)$ \\
\hline $\begin{array}{l}\text { GAD-7, mean } \\
\text { (SD) }\end{array}$ & $\begin{array}{l}n=198 ; 93.8 \%, 1.50 \\
(2.15)\end{array}$ & $\begin{array}{l}n=74 ; 94.9 \%, 2.31 \\
(2.63)\end{array}$ & $\begin{array}{l}n=2332,,^{28} 2.66 \\
(3.24)\end{array}$ & $\begin{array}{l}n=178 ; 98.3 \%, 2.79 \\
(2.30)\end{array}$ & $\begin{array}{l}n=2698,{ }^{28} 3.20 \\
(3.52)\end{array}$ \\
\hline$<10$ & $196(99.0 \%)$ & $72(97.3 \%)$ & $94.0 \% *$ & $176(98.9 \%)$ & $94.0 \%{ }^{\star}$ \\
\hline $10-14$ & $1(0.5 \%)$ & $2(2.7 \%)$ & $4.7 \%$ * & $2(1.1 \%)$ & $4.7 \%{ }^{*}$ \\
\hline$>14$ & $1(0.5 \%)$ & 0 & $1.3 \% *$ & 0 & $1.3 \%$ * \\
\hline
\end{tabular}

CES-D, Centre of Epidemiologic Studies Depression Scale; GAD, Generalized Anxiety Disorder. 
Table 4 Depression (CES-D) and anxiety (GAD-7) scores for different playing position, level of play and injured/uninjured top-level football players

\begin{tabular}{|c|c|c|c|c|}
\hline & \multicolumn{2}{|l|}{ Male } & \multirow{2}{*}{$\begin{array}{l}\text { Female } \\
\text { First league players }\end{array}$} & \multirow[b]{2}{*}{ All } \\
\hline & First league players & U-21 players & & \\
\hline$C E S-D$ & mean (SD) & mean (SD) & mean (SD) & mean (SD) \\
\hline Playing position & $N=179$ & $\mathrm{~N}=73$ & $N=176$ & $N=428$ \\
\hline Defender & $7.09(4.49)$ & $12.1(7.00)$ & $8.86(6.02)$ & $8.59(5.80)$ \\
\hline Midfielder & $6.41(4.38)$ & $8.42(5.57)$ & $8.81(4.30)$ & $7.76(4.71)$ \\
\hline Attacker & $9.52(5.80)$ & $8.40(5.08)$ & $11.48(6.57)$ & $10.1(6.00)$ \\
\hline Goalkeeper & $5.91(3.41)$ & $9.80(4.66)$ & $10.11(6.85)$ & $8.07(5.52)$ \\
\hline More than one & $8.13(5.87)$ & $13.8(8.08)$ & $13.38(5.61)$ & $11.5(6.59)$ \\
\hline Level of play & $\mathrm{N}=182$ & $\mathrm{~N}=73$ & $\mathrm{~N}=177$ & $\mathrm{~N}=432$ \\
\hline >9 internat. matches & 7.03 (5.59) & $7.30(5.74)$ & $8.79(5.21)$ & $7.73(5.45)$ \\
\hline >19 national matches & $6.96(4.62)$ & $8.38(5.04)$ & $9.13(5.83)$ & $8.06(5.10)$ \\
\hline$>20$ national matches & $7.97(4.43)$ & $12.29(6.75)$ & $10.95(6.47)$ & $10.33(6.16)$ \\
\hline Currently injured & $\mathrm{N}=178$ & $N=73$ & $N=176$ & $\mathrm{~N}=427$ \\
\hline No & $7.00(4.54)$ & $9.37(6.39)$ & $9.38(5.41)$ & $8.33(5.34)$ \\
\hline Yes & $7.64(5.84)$ & $11.75(5.27)$ & $10.1(7.73)$ & $9.74(6.28)$ \\
\hline \multicolumn{5}{|l|}{$G A D-7$} \\
\hline Playing position & $\mathrm{N}=195$ & $\mathrm{~N}=74$ & $\mathrm{~N}=177$ & $N=446$ \\
\hline Defender & $1.51(2.58)$ & $2.25(2.59)$ & $2.70(2.34)$ & $2.13(5.53)$ \\
\hline Midfielder & $1.13(1.37)$ & $2.06(2.19)$ & $2.53(2.02)$ & $1.85(1.92)$ \\
\hline Attacker & $2.17(2.73)$ & $1.73(2.20)$ & $2.68(2.32)$ & $2.27(2.49)$ \\
\hline Goalkeeper & $1.48(1.73)$ & $3.40(2.19)$ & 3.68 (3.07) & $2.57(2.59)$ \\
\hline More than one & $2.11(2.32)$ & $4.40(5.51)$ & $4.00(1.51)$ & $3.32(3.11)$ \\
\hline Level of play & $\mathrm{N}=198$ & $\mathrm{~N}=74$ & $\mathrm{~N}=178$ & $\mathrm{~N}=450$ \\
\hline >9 internat. matches & $1.53(1.97)$ & $0.60(0.84)$ & $2.25(1.82)$ & $1.65(1.86)$ \\
\hline$>19$ national matches & $1.40(2.14)$ & $2.09(2.73)$ & $2.68(2.15)$ & $2.03(2.30)$ \\
\hline$>20$ national matches & $1.74(2.33)$ & $3.10(2.64)$ & $3.37(2.81)$ & $2.70(2.68)$ \\
\hline Currently injured & $\mathrm{N}=193$ & $\mathrm{~N}=74$ & $\mathrm{~N}=177$ & $\mathrm{~N}=444$ \\
\hline No & $1.39(2.01)$ & $2.03(2.62)$ & $2.69(2.22)$ & $1.99(2.27)$ \\
\hline Yes & $1.73(2.36)$ & $3.31(2.50)$ & $3.11(2.60)$ & $2.69(2.56)$ \\
\hline
\end{tabular}

CES-D, Centre of Epidemiologic Studies Depression Scale; GAD, Generalized Anxiety Disorder.

were statistically significantly $(\mathrm{t}=1.99 ; \mathrm{p}<0.05)$ only for the entire group.

\section{Anxiety}

Almost all players $(95.5 \%)$ answered the GAD-7 without any differences between the subgroups. The anxiety score of the entire group was on average $2.14(\mathrm{SD}=2.37)$, and indicated an at least moderate anxiety disorder in 6 $(1.4 \%)$ players. Three $(50 \%)$ of the six players with an anxiety disorder also had a depression. The GAD-7 score correlated significantly with the CES-D score $(r=0.584$; $\mathrm{p}<0.001)$, age $(\mathrm{r}=-0.120 ; \mathrm{p}<0.05)$ and number of matches $(\mathrm{r}=-0.204 ; \mathrm{p}<0.001)$ but not with number of injuries in the previous 12 months.

Male FL players had significantly lower average anxiety scores than male $\mathrm{U}-21 \quad(\mathrm{t}=2.26 ; \mathrm{p}<0.05)$, female $\mathrm{FL}$ players $(\mathrm{t}=5.00 ; \mathrm{p}<0.001)$ and the general population $(\mathrm{t}=4.96 ; \mathrm{p}<0.001)$. The average anxiety scores of $\mathrm{FL}$ female players and of male U-21 players were similar to the general population of the same gender. The percentage of players with GAD-7 scores indicating anxiety disorder was similar in the three subgroups, and in the entire group, significantly lower than in the general population $\left(\chi^{2}=16.9 ; \mathrm{p}<0.001\right)$ (for details see table 3 ).
The average anxiety score differed significantly between playing positions $(\mathrm{F}=2.46 ; \mathrm{p}<0.05)$ and the three levels of play $(\mathrm{F}=5.17 ; \mathrm{p}=0.01)$ for the entire group (for details see table 4). In the subgroups, differences were only significant for levels of play in U-21 players $(\mathrm{F}=3.91 ; \mathrm{p}<0.05)$. Injured players had higher average anxiety score than uninjured players in the three subgroups, but the result was statistically significantly $(t=2.20 ; p<0.05)$ only for the entire group.

\section{DISCUSSION}

For the evaluation of a prevalence rate, it is extremely important to investigate a representative group of the target population. The lower the expected prevalence the more important the sample size and response rate to avoid a potential response bias. A low response rate can falsify the true prevalence when primarily people show interest in or are affected by the topic answer, or the opposite, for example, when the subject is stigmatised. Therefore, entire teams and almost the entire first Swiss football league were included in the present study. With a total of 471 players, our sample is larger than others in studies on the mental health of athletes. More 
importantly, all players of 23 teams took part in the study, and $92 \%$ filled in the depression and $96 \%$ the anxiety questionnaire. Thus, response rate in the present study is higher than in any previous study in this area.

The prevalence of depression in the present study was $9 \%$ in male and $13 \%$ in female players. These proportions are similar to the general population, ${ }^{29}$ but substantially lower than those of six other studies on athletes, using the same questionnaire and cut-off score $\left(15.6 \%{ }^{15}\right.$ to $\left.33.5 \%{ }^{12}\right)$, and also lower than those of five studies using other assessment methods in athletes, ${ }^{17} 2022-24$ but higher than those reported by Storch et $a l^{18}$ and Schaal $e t a l^{21}$ (for details see table 1).

The prevalence of an at least moderate anxiety disorder was $1.4 \%$ in the present study and, thus, significantly lower $\left(\chi^{2}=16.7 ; \mathrm{p}<0.001\right)$ than in the general population $(6 \%),{ }^{28}$ lower than reported by Gulliver et $a l^{19}(7.1 \%)$, using the same questionnaire and cut-off, and lower than in other studies using different assessment methods on athletes. ${ }^{13} 1418{ }^{21}$ However, a significant correlation was observed between depression and anxiety, as reported previously. ${ }^{13} 21$

The differences between the present and previous studies might be due to the assessment methods and/or response rates (as outlined above), but could also be influenced by characteristics of investigated athletes, such as age, gender, sport, level of skill and nationality. In the present study, several significant differences in depression and anxiety were observed with regard to player characteristics. The higher prevalence of depression in female than in male players found in the present study is in agreement with previously studies on athletes ${ }^{12} 13 \quad 18-20$ and on the general population. ${ }^{28} 29$ Injured players had higher scores for depression and anxiety than uninjured players, as previously described (for overview see Ref. 11). Attackers and players playing in more than one playing position had the highest, and midfielder the lowest, average depression score. Similar results have been reported on top-level German female players (Prinz and Junge, submitted). The average depression score decreased with a higher level of play, and was lower in male FL players than in U-21 players. These results are in agreement with Nixdorf $e t a l^{20}$ who reported different prevalence rates of depression in professionals (15\%), and junior (20\%) and amateur athletes (29\%), even if their prevalence rates were higher. These results might explain (in addition to the differences in the response rate) why the top-level football players investigated in the present study had a lower prevalence of depression than reported from NCAA Division I athletes (see table 1).

In the present study, male and female FL players had similar average depression scores as the general population, but U-21 players had significantly higher scores. Consequently, $6.6 \%$ of male FL players had an at least mild to moderate depression compared to $15.1 \%$ of the U-21 players. The latter percentage is similar to the prevalence rates reported for male division I baseball players $\left(15.6 \%^{15}\right)$, and closer to the prevalence reported for NCAA Division I American Football players $\left(20 \%{ }^{14}\right)$ and male NCAA Division I athletes from various sports $\left(19 \%^{13}\right)$. Thus, the present study perfectly complements the current knowledge on mental health problems of athletes in a survey on top-level male and female football players.

Although 13 players in the present study had depression scores indicating major depression, only $1(0.2 \%)$ took antidepressants. The low intake of antidepressants in athletes was previously reported by Machnik $e t a l,{ }^{30}$ who analysed urine samples collected from doping control over a 10-year period, and found $0.14 \%$ positive for antidepressants in football players. Prinz and Junge (submitted) reported that almost $40 \%$ of top-level German female football players wanted or needed psychological support at least once during their careers, but only $10 \%$ received it. These results demonstrate that depression and other mental health problems are an under-regarded and often not sufficiently treated aspect of athletes' health.

\section{CONCLUSION}

Swiss FL football players are at the same risk for depression and anxiety as the general population, while male U-21 players have a higher prevalence of depression than the general male population. Significant differences in the depression and anxiety were observed with regard to player characteristics, such as age, gender, player positions, level of play and current injury. Future studies on mental health problems in athletes should further analyse such differences to identify risk factors and athletes at risk. On average, symptoms of a severe depression were present in one player of each female FL team and of each male U-21 team, as well as in one player in two male FL teams. But only one player reported taking antidepressants. Thus, it is important to raise awareness and knowledge of athletes' mental health problems in coaches and team physicians, and to provide adequate psychotherapeutic and/or pharmacological treatment to athletes in need.

Acknowledgements The authors highly appreciate the cooperation of all the players who volunteered their time to fill in the questionnaire. They thank the test administrators for distributing the questionnaire and helping to achieve the high response rate. They express their gratitude to Dzimitry Katsiuba for data entry and his assistance in the statistical analysis. The authors gratefully acknowledge the Fédération Internationale de Football Association (FIFA) for funding this study.

Competing interests None declared.

Patient consent Obtained.

Ethics approval ethic commission Kanton Zürich, Switzerland.

Provenance and peer review Not commissioned; internally peer reviewed.

Data sharing statement No additional data are available.

Open Access This is an Open Access article distributed in accordance with the Creative Commons Attribution Non Commercial (CC BY-NC 4.0) license, which permits others to distribute, remix, adapt, build upon this work noncommercially, and license their derivative works on different terms, provided the original work is properly cited and the use is non-commercial. See: http:// creativecommons.org/licenses/by-nc/4.0/ 


\section{REFERENCES}

1. Reng R, Enke R. Ein allzu kurzes Leben. Piper Verlag, 2010.

2. Biermann A, Schäfer R. Rote Karte Depression: Das Ende einer Karriere im Profifußball. Gütersloher Verlagshaus, 2011.

3. Rafati B. Ich pfeife auf den Tod! Wie mich der Fußball fast das Leben kostete. Kösel-Verlag, 2013.

4. Cooney GM, Dwan K, Greig CA, et al. Exercise for depression. Cochrane Database Syst Rev 2013;(9):CD004366.

5. Mammen G, Faulkner G. Physical activity and the prevention of depression: a systematic review of prospective studies. Am J Prev Med 2013;45:649-57.

6. Gulliver A, Griffiths KM, Christensen H. Barriers and facilitators to mental health help-seeking for young elite athletes: a qualitative study. BMC Psychiatry 2012;12:157.

7. Glick ID, Stillman MA, Reardon CL, et al. Managing psychiatric issues in elite athletes. J Clin Psychiatry 2012;73:640-4.

8. Schwenk TL. The stigmatisation and denial of mental illness in athletes. Br J Sports Med 2000;34:4-5.

9. Reardon CL, Factor RM. Sport psychiatry: a systematic review of diagnosis and medical treatment of Mental IIIness in Athletes. Sports Med 2010;40:961-80

10. Frank R, Nixdorf I, Beckmann J. Depression among elite athletes: prevalence and psychological factors. Deut $Z$ Sportmed 2013;64:320-6.

11. Wolanin A, Gross M, Hong E. Depression in athletes: prevalence and risk factors. Curr Sports Med Rep 2015;14:56-60.

12. Armstrong S, Oomen-Early J. Social connectedness, self-esteem, and depression symptomatology among collegiate athletes versus non-athletes. J Am Coll Health 2009;57:521-6.

13. Yang J, Peek-Asa C, Corlette JD, et al. Prevalence of and risk factors associated with symptoms of depression in Competitive Collegiate Student Athletes. Clinical J Sport Med 2007;17:481-7.

14. Yang J, Cheng G, Zhang $Y$, et al. Influence of symptoms of depression and anxiety on injury hazard among collegiate American football players. Res Sports Med 2014;22:147-60.

15. Proctor SL, Boan-Lenzo C. Prevalence of depressive symptoms in male intercollegiate student-athletes and non-athletes. J Clin Sport Psychol 2010;4:204-20.

16. Brewer WB, Petrie TA. A comparison between injured and uninjured football players on selected psychosocial variables. Acad Athlete $J$ 1995; 10:11-18.
17. Weigand S, Cohen J, Merenstein D. Susceptibility for depression in current and retired student athletes. Sports Health 2013;5: 263-6.

18. Storch EA, Storch JB, Killiany EM, et al. (2005) Self-reported psychopathology in athletes: a comparison of intercollegiate student-athletes and non-athletes. J Sport Behav 2005;28: 86-98.

19. Gulliver A, Griffiths KM, Mackinnon A, et al. The mental health of Australian elite athletes. J Sci Med Sport 2015;18:255-61.

20. Nixdorf I, Frank R, Hautzinger M, et al. Prevalence of depressive symptoms and correlating variables among German elite athletes. $J$ Clin Sport Psychol 2013;7:313-26.

21. Schaal $\mathrm{K}$, Tafflet $\mathrm{M}$, Nassif $\mathrm{H}$, et al. Psycholgical balance in high level athletes: gender-based differences and sport-specific patterns. PLOS ONE 2011;6:e19007.

22. Spengler A, Schneider G, Schröder E. Depressivität-Screening und Vorkommen in der sportmedizinischen Praxis. Deut $Z$ Sportmed 2013;64:65-8.

23. Gouttebarge V, Frings-Dresen MH, Sluiter JK. Mental and psychosocial health among current and former professional footballers. Occup Med 2015;65:190-6.

24. Hammond T, Gialloreto C, Kubas H. The prevalence of failure-based depression among elite athletes. Clin J Sport Med 2013;23:273-7.

25. Radloff LS. The CES-D scale a self-report depression scale for research in the general population. Appl Psych Meas 1977:1:385-401.

26. Spitzer RL, Kroenke K, Williams JB, et al. A brief measure for assessing generalized anxiety disorder: the GAD-7. Arch Intern Med 2006;166:1092-7.

27. Hautzinger M. Die CES-D Skala. Ein Depressionsmessinstrument für Untersuchungen in der Allgemeinbevölkerung. Diagnostica 1988:34:167-73.

28. Löwe B, Decker O, Müller S, et al. Validation and standardization of the Generalized Anxiety Disorder Screener (GAD-7) in the general population. Med Care 2008;46:266-74.

29. Stein J, Luppa M, Mahnke J, et al. Screening for depression by telephone using the German version of the Center for Epidemiological Studies Depression Scale (CES-D). Psychiatr Prax 2014;41:135-41.

30. Machnik M, Sigmund G, Koch A, et al. Prevalence of antidepressants and bio-similars in elite sport. Drug Test Anal 2009;1:286-91. 